\title{
Identification of Historic Homestead and Orchard Apple Cultivars in Wyoming
}

\author{
Jonathan Magby ${ }^{1}$ \\ University of Wyoming, 1000 University Avenue, Laramie, WY 82071
}

Gayle M. Volk and Adam Henk

U.S. Department of Agriculture-Agricultural Research Service National Laboratory for Genetic Resources Preservation, 1111 South Mason Street, Fort Collins, CO 80521

\author{
Steve Miller ${ }^{1}$ \\ University of Wyoming, 1000 University Avenue, Laramie, WY 82071
}

Additional index words. cold-hardy, heritage, Malus $\times$ domestica, SSR

\begin{abstract}
Thousands of apple trees were planted in Wyoming's orchards and homesteads in the 1800s, many of which are still alive today. Unfortunately, cultivar identity of these trees has mostly been lost or obscured. The purpose of this research was to identify heritage apple cultivars in Wyoming using genetic fingerprinting (microsatellite) techniques and to use this information to make recommendations on candidate coldhardy cultivars for specialty crop and breeding programs. Leaf samples were collected from 510 heritage apple trees from 91 sites in 19 locales across Wyoming. Known cultivars from the U.S. Department of Agriculture (USDA)-National Plant Germplasm System, Seed Savers Exchange, and Washington State University apple collections were used as standards to determine cultivar identities. Overall, $328(64 \%)$ of the previously unidentified apples trees were identified to 47 known cultivars. Fifteen of these known cultivars comprised more than $80 \%$ of the samples that were identified, with all 15 of those cultivars developed in states and countries with average temperatures or winter conditions similar to Wyoming. Seventy-one of the heritage trees were identified as the Wealthy cultivar. Other commonly identified cultivars were Haralson, Patten's Greening, Yellow Transparent, Northwestern Greening, and McMahon. It is likely that a combination of popularity and cultivar origin affected the choice of cultivars that were grown in Wyoming. Although most original Wyoming heritage apple trees are reaching the end of their life span, many surviving trees continue to produce fruit. This strongly suggests that despite lower resistance to certain pathogens than many modern cultivars, these heritage trees should be considered for use today. The results provide insights into possible cultivars that could be grown in Wyoming and also in other states with similar harsh growing conditions.
\end{abstract}

The state of Wyoming has some of the driest and coldest winters in the lower 48 states, with a ranking of fourth in average low temperature and fifth in average low precipitation [National Oceanic and Atmospheric Administration (NOAA), 2018]. Although apples are not usually grown in conditions such as these, remnants of apple orchards from the late 19th and early 20th centuries can still be found surviving in Wyoming's rugged landscape. The Ed. Young Orchard, in Lander, WY, dates to the 1880 s and was the first documented commercial orchard recorded in Wyoming. It contained roughly 3000 trees in its prime, making it the largest orchard ever in the state of Wyoming. The Lander Experimental Fruit Farm was originally homesteaded by William Nichols (1873), later purchased by the residents of Lander for the State Agricultural College (1892), and then donated to the University of Wyoming (e.g., University of Wyoming Lander Experimental Fruit Farm) in 1917 (Morneau et al., 2016). This University of

Wyoming Lander Experimental Fruit Far Orchard contained 1700 trees of 175 cultivars by the early 1920s and contained the largest cultivar diversity in the state. Between these two orchards, only 127 trees of the original 4700 remain (Miller, 2014).

Between 1870 and 1940, more than 200 apple cultivars were tested and/or reported to be successfully growing in Wyoming. These cultivars came from breeding programs in 28 states and six countries (Magby and Miller, 2018). Cultivars originated from breeding programs and nurseries including Stark Bros Nursery (Louisiana, MO), New York Agricultural Experiment Station (Geneva, NY), C.G. Patten Orchard (Charles City, IA), Peter Gideon Orchard (Excelsior, MN), and the University of Minnesota Experiment Station (St. Paul, MN), as well as other breeding programs in Wisconsin, South Dakota, Russia, and Canada. These cultivars were successfully grown under the windy, cold, and droughtprone Wyoming conditions. 'Wealthy' (MN) and 'Alexander' (Russia) were likely parents of novel cultivars selected specifically for Wyoming conditions. The University of Wyoming Lander Experimental Fruit Farm was run by Superintendent John Steinbreck from 1907 until his death in 1939. The 10 cultivars bred by superintendent John Steinbreck at the University of Wyoming Lander Experimental Fruit Farm include Margaret, Fremont, Poposia, Mart, Nelson, Roberts, Sundance, Washakie, WyomingFremont, and Brechsteinia, named by Aven Nelson (Magby and Miller, 2018).

Many heritage apple trees in Wyoming have not been maintained for up to a century, and a number have succumbed to winter damage as well as diseases and pests. Trees that have survived these harsh conditions may yield insights into cultivars that could be grown by homeowners and future Wyoming fruit crop producers. Morphological traits have most commonly been used to identify apple cultivars (Burford, 2013; Bussey and Whealy, 2016; Calhoun, 2010; Smith, 2002). However, apple cultivars have high levels of phenotypic plasticity (e.g., broad phenotypic variation under environmental stimuli), making such methods unreliable (Routson et al., 2009). A much more reliable method of cultivar identification is through the use of molecular techniques. Apple cultivars have been reliably identified using genetic fingerprinting techniques (microsatellites) because they have a high level of polymorphism, are codominant, and are inherited in a Mendelian fashion (Wünsch and Hormaza, 2001).

The goal of this research was to identify heritage cultivars planted in Wyoming's homesteads, orchards, and nurseries as early as 1870 . We used microsatellite markers to identify the cultivars represented across Wyoming's landscape to provide future specialty crop growers and/or local growers with recommendations for cultivar selection. This information will allow production and breeding programs to select existing cultivars to improve drought and cold tolerance in apple cultivars.

\section{Materials and Methods}

Source plant material. A total of 510 apple leaf samples were collected from 91 historic orchards, farms and ranches, and homesteads occurring in 19 locales across northeast, northwest, central, and southeastern portions of the state of Wyoming (Fig. 1; Table 1). The source locales and sites were selected using information obtained from word-ofmouth interviews and from Wyoming Agricultural Bulletins (WGB) and Experimental Fruit Farm Bulletins (EFFB) that listed owners (nurseries, orchards, and homesteads) and cultivars of apple trees grown between 1870 and 1940 (Nelson, 1905, 1907, 1909, 1912, 1915, 1916, 1918a, 1918b, 1924-25; University of Wyoming Agricultural Experiment Station, 1897). Preference was given to the locales with greatest number of nurseries, orchards, and homesteads, and sites were selected based on the diversity of cultivars 


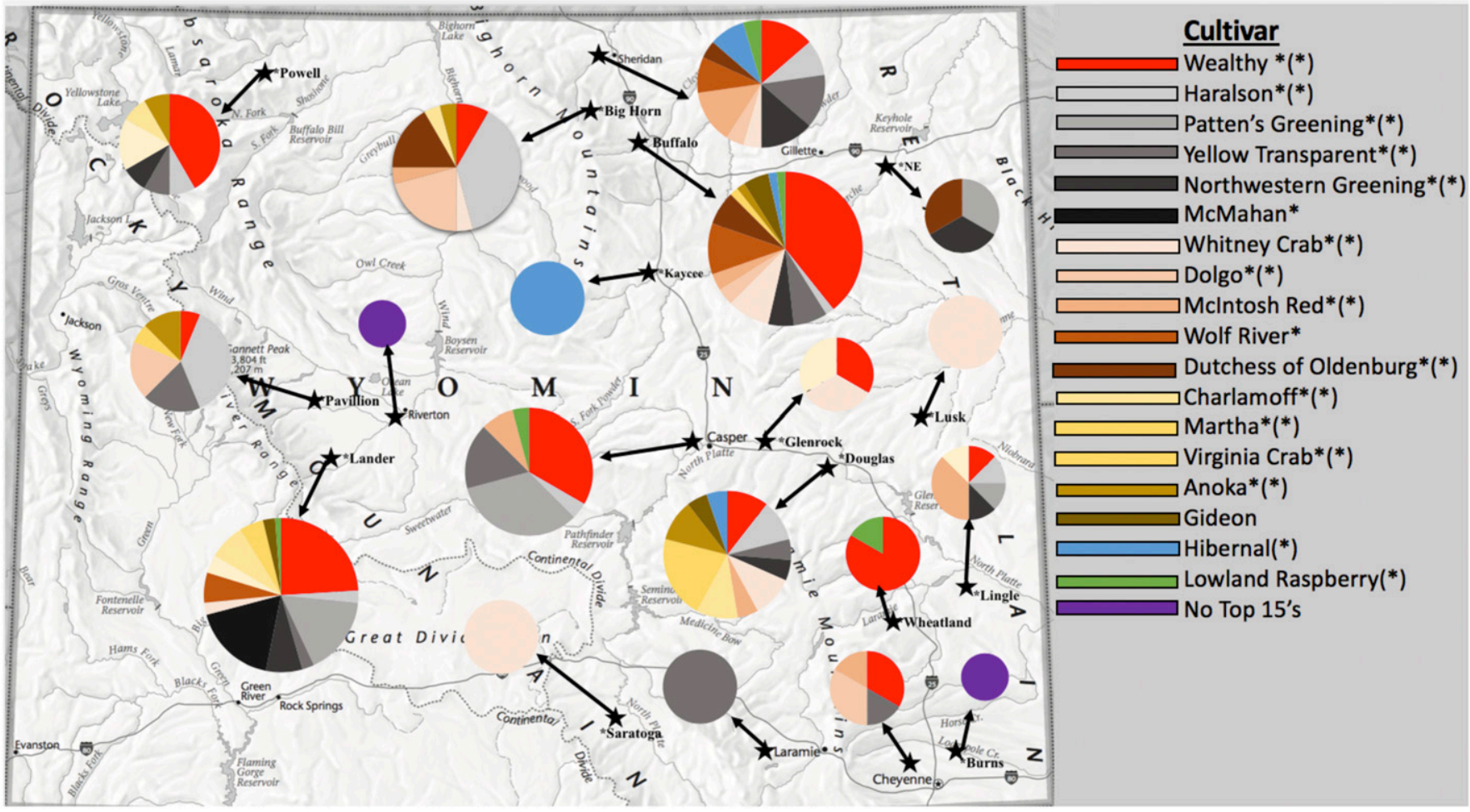

Fig. 1. Cultivar distributions (pie charts) associated with cities (stars) from which previously unidentified heritage apple trees were sampled across Wyoming. Pie chart sizes correspond to the number of samples taken from that locale. Asterisks identify the 15 most commonly identified cultivars * and the 15 cultivars found in the most $(*)$ locales (Source cities in Wyoming). Total trees identified for each city was calculated using both $\mathrm{T}=0$ and $\mathrm{T}=2 \mathrm{matches}$. Note: Error in Figure 1 , Gideon* (e.g., top 15 identified). For more information on the cultivars visit our website at wyomingappleproject.com (National Geographic Society, 2014).

reported in WGB and EFFB bulletins (Magby and Miller, 2018).

Leaf sample collection. When information was available (i.e., the names of the cultivars planted at a given site), subsampling

Received for publication 30 July 2018. Accepted for publication 9 Nov. 2018.

We thank Catherine E. Wagner and Brian A. Mealor for their help over the years. We thank all who have provided funding for this project: the U.S. Department of Agriculture-National Institute of Food and Agriculture, the University of Wyoming Agriculture Experiment Station, and the Wyoming Department of Agriculture Specialty Crop Program. Thank you Dr. Brian Scheffler and Sheron Simpson of the USDA-ARS for genotyping assistance. In addition, we are grateful to C. Thomas Chao, Nicholas Howard, and Carol Ann Miles for providing leaf samples of reference cultivars used in this study. Thank you to all the orchards and tree owners who provided access to their trees. Finally, a special thanks to Nannette Slingerland of the Spear S (formerly Ed. Young) Produce Company, Keith Murray of the Murraymere Farms Orchard, and Joanne Slingerland of the Central Wyoming College Field Station apple restoration project.

For more information on the quality of growth, characteristics, use, year, origin, synonyms, parentage, and disease resistance of Wyoming apple cultivars, please visit our website at www. wyomingappleproject.com. Note: for PC and/or nonApple platforms, Google search Wyoming apple project or allow access through Sophos Anti-Virus protection.

${ }^{1}$ Corresponding author. E-mail: jmagby1@yahoo. com or fungi@uwyo.edu. was performed to avoid overrepresenting a specific cultivar in the data set and/or to avoid sampling seedling trees. When trees were found outside the orchard (i.e., away from the main orchard or outside the normal standard planting rows growers established), they were noted as possible seedlings. Other locations, such as homesteads, did not always plant in rows. The presence of grafting marks helped identify whether trees were likely to be cultivars or seedlings. Landscape drawings, metal tags with a numerical identifier, and GPS coordinates were used to document each tree that was sampled. Known cultivars from the USDANational Plant Germplasm System (NPGS), Seed Savers Exchange, and Washington State University apple collections were used as comparison standards to determine cultivar identities. Standards were selected using information gathered in WGB and EFFB bulletins that listed cultivars reported in Wyoming. Additionally, Magby et al. (2018, unpublished) sourced 96 nursery catalogs to determine the reliability of each cultivar being found in Wyoming. Leaves of reference cultivars were received from the USDA-Agricultural Research Service NPGS (210 cultivars), Seed Savers Exchange (121 cultivars), and Washington State University-Mount Vernon (79 cultivars), and processed in the same manner. In addition, previously published genotypes for 1200 NPGS apple cultivars were used as standards (Gross et al., 2018).

Genotyping. DNA extractions were carried out using previously described procedures (Gross et al., 2012; Hokanson et al., 1998; Routson et al., 2009; Volk et al., 2005) and DNA extraction kits (Qiagen, Germantown,
MD). Samples were processed using previously developed simple sequence repeat (SSR) primers (ChF02, CHh01, Chd08, GD12, GD15, GD96, GD142, GD147, and GD162) (Gross et al., 2012, 2018). Labeled M13 forward and reverse tailed (e.g., 6 of 9) fluorescent primers and labeled M13 forward and reverse (e.g., 3 of 9) (Thermo Fisher Scientific, Waltham, MA) were incorporated during polymerase chain reaction, and fragments were separated on an AB13730 capillary sequencer (Thermo Fisher Scientific, Waltham, MA) using the Liz 500 (Thermo Fisher Scientific) size standard.

Marker data analysis. Fragment lengths were determined using a partially automated binning system software (Gene Mapper version X, Thermo Fisher Scientific). Automated binning was set to a range of $0.4 \pm$ to reduce any chance of more than a single bp being considered the same allele. Allele peaks were manually checked for accuracy if they were not clearly binned. Scores for unknowns were manually compared with references across all nine primers using function data sort in Microsoft Excel (version 2017; Microsoft, Redmond, WA). In addition, the multilocus match function was implemented in GenAlEx (version 6.5) to further confirm genetic clones (Peakall and Smouse, 2006). We implemented the standards for determining genetic clones as described in Gross et al. (2018), as follows: $\mathrm{T}=0$ (i.e., no mismatches at any loci) and $\mathrm{T}=2$ (i.e., mismatches to two steps at either one locus or among two different loci)

A manual allele correction was performed to correct the newly collected data with an 
Table 1. The number of trees sampled from 91 sites in 19 locales across Wyoming.

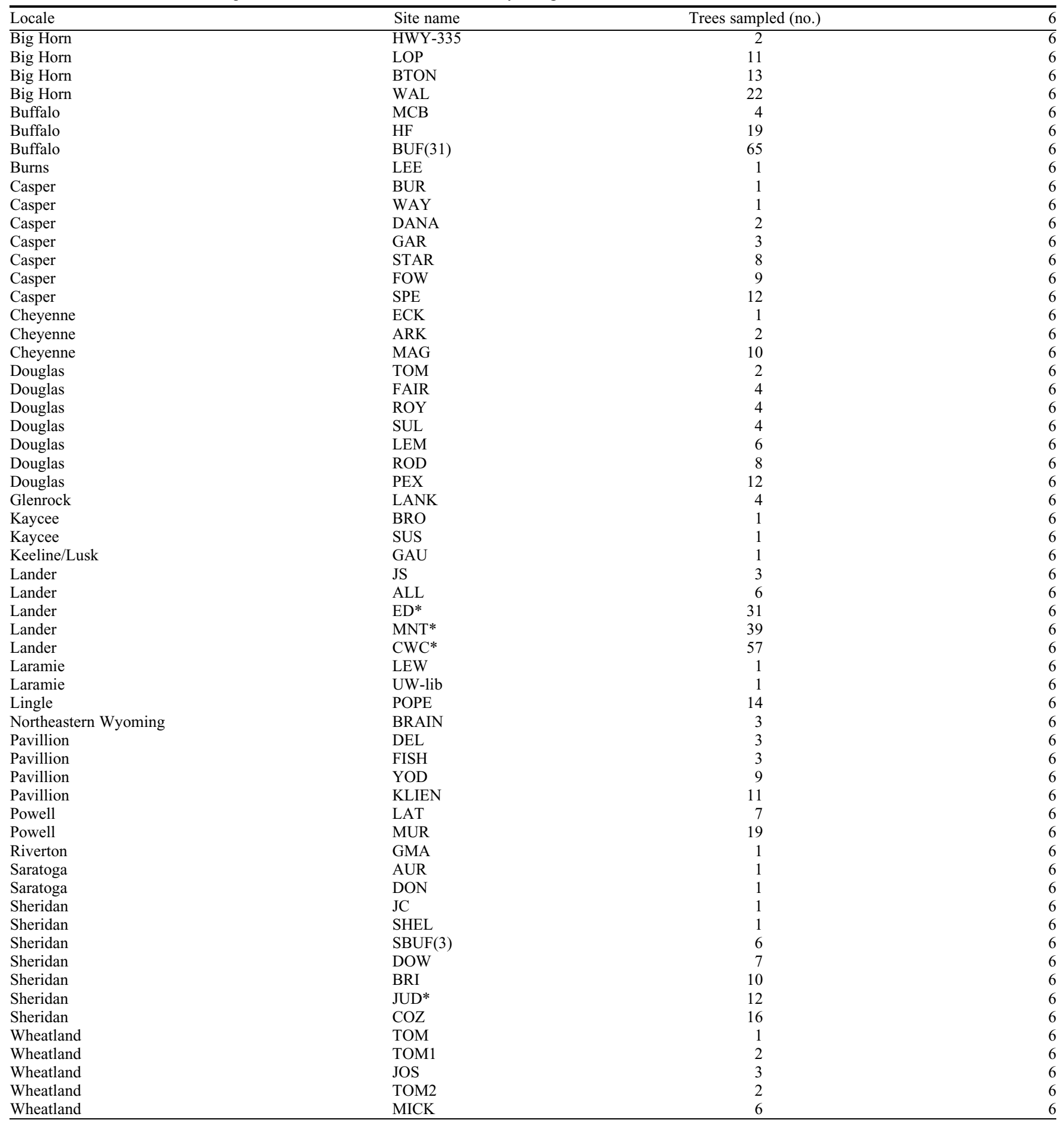

Samples taken from residents within the city limits of Buffalo (BUF) and Sheridan (SBUF) were combined but are not considered as a single site in our calculations [i.e., BUF (31) and SBUF (3)]. Included is the locale, site name, number of trees sampled, and total trees identified to cultivar. Samples obtained from the historic Ed. Young (ED) and University of Wyoming Lander Experimental Fruit Farm (MNT \& CWC) are coded with $\left({ }^{*}\right)$.

additional 1200 NPGS apple cultivars, as described by Gross et al. (2018). To provide evidence that the combined data sets were sufficient to determine clonal duplicates, multilocus probability of identity (ProbI) was calculated in GenAlEx 6.5. ProbI estimates the average probability two unrelated individuals from the same population will have identical multilocus genotypes (Peakall and Smouse, 2006). The real value is likely between ProbI (standard) and Prob sibs $_{\text {(con- }}$ servative), so both were implemented (Gross et al., 2012). Calculations for expected heterozygosity $\left(H_{\mathrm{e}}\right)$, observed heterozygosity $\left(H_{\mathrm{o}}\right)$, and total number of alleles were calculated in GenAlEx 6.5 using all nine SSRs (Peakall and Smouse, 2006).

\section{Results}

A total of 510 previously unidentified heritage apple trees were sampled from 91 sites in 19 locales (Table 1; Fig. 1). Eleven of the 19 locales across Wyoming from which samples were taken had a minimum of 13 and a maximum of 136 trees sampled. Lander, WY (136), and Buffalo, WY (88), had the greatest number of sampled trees (Table 1). Locales with the highest number of sampling sites were Buffalo (33), Sheridan (9), Casper (7) and Douglas (7), and a single site was sampled in Burns, Glenrock, Lusk, Lingle, and northeast Wyoming (near Gillette) (Table 1). 
A total of 328 previously unidentified apple trees matched 47 reference cultivars (Table 2). Three hundred three of the identifications matched at the $\mathrm{T}=0$ threshold. In addition, 25 more identifications matched at the $\mathrm{T}=2$ threshold (Table 2 ). Four unknown samples had missing data after two rounds of genotyping. On the basis of the eight loci that could be scored, one unknown sample was determined to be the cultivar Patten's Greening (Gross et al., 2012).

Twenty-eight of the 47 cultivars were found more than once in our data set, and 22 cultivars occurred in more than one locale in Wyoming. Wealthy was the most frequently identified cultivar. Other commonly identified cultivars were Haralson, Patten's Greening, Yellow Transparent, Northwestern Greening, McMahon, Whitney Crab, Dolgo, McIntosh Red, Wolf River, Dutchess of Oldenburg, Charlamoff, Martha, Virginia Crab, and Anoka (Table 2). In Wyoming, Wealthy, Haralson, and Yellow Transparent were the only cultivars that were identified more than 16 times and in more than nine locales (Table 2). These three cultivars, as well as some of the other identified cultivars, were selected or developed for climates with similar winter conditions to Wyoming (e.g., Minnesota and Russia).

'Wealthy' was identified the most frequently (71) and occurred in the most locales across Wyoming (12) (Table 2). 'Wealthy' was found the most frequently in Buffalo (22 trees from 14 sites) and Lander (19 trees from 4 sites) and was the top and/or tied for the most identified cultivar in eight locales sampled (Table 3). 'Wealthy' was introduced in Excelsior, MN (1868), by Peter M. Gideon, who named it in honor of his wife (Bussey and Whealy, 2016). Characteristics of 'Wealthy' include, medium to large size, thick green skin marked by blushes, narrow stripes of crimson, and splashes of red (Bussey and Whealy, 2016; Magby and Miller, 2018). Of the seven locales where 'Wealthy' was not found, six had fewer than three trees sampled. These six locales may not reflect the absence of the Wealthy cultivar but instead a low sampling level (Fig. 1). 'Wealthy' was determined to be highly resilient under Wyoming conditions by the University of Wyoming Lander Experimental Fruit Farm and was referenced more times than any other apple (44) in WGB and EFFB bulletins (Nelson, 1905, 1907, 1909, 1912, 1915, 1916, 1918a, 1918b, 1924-25; University of Wyoming Agricultural Experiment Station, 1897).

'Haralson' was found in nine locales and occurred 25 times in Wyoming. 'Haralson' was most frequently identified in Big Horn (nine trees from three sites) and Pavillion (six trees from four sites) (Table 3; Fig. 1). There was no record in WGB and EFFB bulletins of 'Haralson' being tested or grown in Wyoming. 'Haralson' originated in Minnesota and was distributed around 1918. It is believed to be a cross between the cultivars Malinda $\times$ Wealthy and is characterized by medium- to large-size fruit that have greenish yellow skin overlaid with brownish red (Bussey and Whealy, 2016; Magby and Miller, 2018).

'Patten's Greening' was found 23 times in Wyoming but only occurred in four locales [Lander, Casper, Lingle, and northeast Wyoming (near Gillette); Table 2; Fig. 1]. Patten's Greening tied for the top cultivar found in Casper and NE Wyoming (Table 3). The apple was named and introduced by C.G. Patten of Charles City, IA (1885), but originated from Portage, WI. 'Patten's Greening' is believed to be a seedling of 'Oldenburg' and is characterized by medium- to large-size fruit that have smooth and clear yellowish green skin and bronze blushes and faint stripes (Bussey and Whealy, 2016; Magby and Miller, 2018). In WGB and EFFB bulletins, 'Patten's Greening' was mentioned six times and was recommended for Wyoming growing conditions by the University of Wyoming Lander Experimental Fruit Farm (Nelson, 1905, 1907, 1909, 1912, 1915, 1916, 1918a, 1918b, 1924-25; University of Wyoming Agricultural Experiment Station, 1897).

'Yellow Transparent' was found 20 times in nine locales (Table 2). 'Yellow Transparent' was identified most frequently in Buffalo (four trees from four sites) and Casper (four trees from three sites) (Table 3). The cultivar originated in Russia and was imported along with many other cultivars of Russian origin in 1870 . It is characterized as a medium to small apple, with clear white skin that becomes pale yellow and sprinkled with light greenish dots (Bussey and Whealy, 2016; Magby and Miller, 2018). 'Yellow Transparent' was more evident in northeastern $(35 \%)$ and central-northwestern $(30 \%)$ portions of the state, as $65 \%$ of its total came from Sheridan, Buffalo, Lander, Pavillion, and Powell, WY (Fig. 1). 'Yellow Transparent' was recommended for Wyoming growing conditions by the University of Wyoming Lander Experimental Fruit Farm and was mentioned 24 times in WGB and EFFB bulletins (Nelson, 1905, 1907, 1909, 1912, 1915, 1916, 1918a, 1918b, 1924-25; University of Wyoming Agricultural Experiment Station, 1897).

'Northwestern Greening' was found 16 times across seven locales in Wyoming. 'Northwest Greening' is characterized as being medium to large, with clear pale yellow or greenish color. It originated in Lola, WI, and was introduced or bred around 1849 (Bussey and Whealy, 2016; Magby and Miller, 2018). 'Northwest Greening' was determined moderately viable for Wyoming conditions by the University of Wyoming Lander Experimental Fruit Farm and was mentioned 11 times in WGB and EFFB bulletins (Nelson, 1905, 1907, 1909, 1912, 1915, 1916, 1918a, 1918b, 1924-25; University of Wyoming Agricultural Experiment Station, 1897).

'McMahon' was found 14 times in Wyoming. It was recommended for Wyoming growing conditions by the University of Wyoming Lander Experimental Fruit Farm. However, 'McMahon' was only identified in Lander, WY (two sites) (Fig. 1; Table 2) (Nelson, 1924-25). It was mentioned seven times in WGB and EFFB bulletins and originated in Bloom, WI (1860) (Bussey and Whealy, 2016; Nelson, 1905, 1907, 1909, 1912, 1915, 1916, 1918a, 1918b; University of Wyoming Agricultural Experiment Station, 1897). 'McMahon' is believed to be a seedling of the cultivar Alexander (Origin Russia) and is large to very large in size, with clear to yellowish white skin that becomes almost clear white when ripe (Bussey and Whealy, 2016; Magby and Miller, 2018).

'Whitney Crab' was found 14 times and was identified in eight locales in Wyoming (Table 2). 'Whitney Crab' was found in multiple Wyoming locales, but the majority of the trees were in or near Sheridan, Big Horn, and Buffalo, WY (Table 2; Fig. 1). 'Whitney Crab' originated from Franklin Grove, IL (pre-1865), which is 59 miles south of the Wisconsin border (Bussey and Whealy, 2016). The apple is described as medium sized, with greenish yellow to light yellow skin with a carmine blush (Bussey and Whealy, 2016; Magby and Miller, 2018). It was recommended for Wyoming conditions by the University of Wyoming Lander Experimental Fruit Farm but was mentioned only four times in WGB and EFFB bulletins (Nelson, 1905, 1907, 1909, 1912, 1915, 1916, 1918a, 1918b, 1924-25; University of Wyoming Agricultural Experiment Station, 1897).

'Dolgo' was found 13 times across five locales in Wyoming and was mostly identified in or near Sheridan, Big Horn, and Buffalo, WY (Table 2; Fig. 1). It was never tested for Wyoming conditions by the University of Wyoming Lander Experimental Fruit Farm or mentioned in WGB and EFFB bulletins. 'Dolgo' was imported from Russia around 1917 and resulted from the open-pollination of wild crab apples Malus baccata and Malus prunifolia (Bussey and Whealy, 2016; Magby and Miller, 2018).

Finally, 'McIntosh Red' and 'Wolf River' were each identified 13 times. 'McIntosh Red' was often found in Sheridan and Lingle, WY, and all 'Wolf River' samples were found in Sheridan, Buffalo, and Lander, WY (Fig. 1; Table 3). 'McIntosh Red' originated in Canada (1780s) and has a medium to large fruit with whitish or pale greenish skin that is blushed and/or striped deep red and a heavy bloom (Bussey and Whealy, 2016; Magby and Miller, 2018). 'McIntosh Red' was determined to be moderately viable for Wyoming conditions by the University of Wyoming Lander Experimental Fruit Farm and was mentioned 12 times in WGB and EFFB bulletins (Nelson, 1905, 1907, 1909, 1912, 1915, 1916, 1918a, 1918b, 1924-25; University of Wyoming Agricultural Experiment Station, 1897). 'Wolf River' was developed in 1852 in Wisconsin and is likely a seedling of the cultivar Alexander (origin Russia) (Bussey and Whealy, 2016). It is described as having large to very large fruit with bright yellow or greenish skin overlaid with bright red stripes and splashes of carmine (Bussey and Whealy, 2016; Magby and Miller, 2018). 'Wolf River' was recommended for Wyoming 


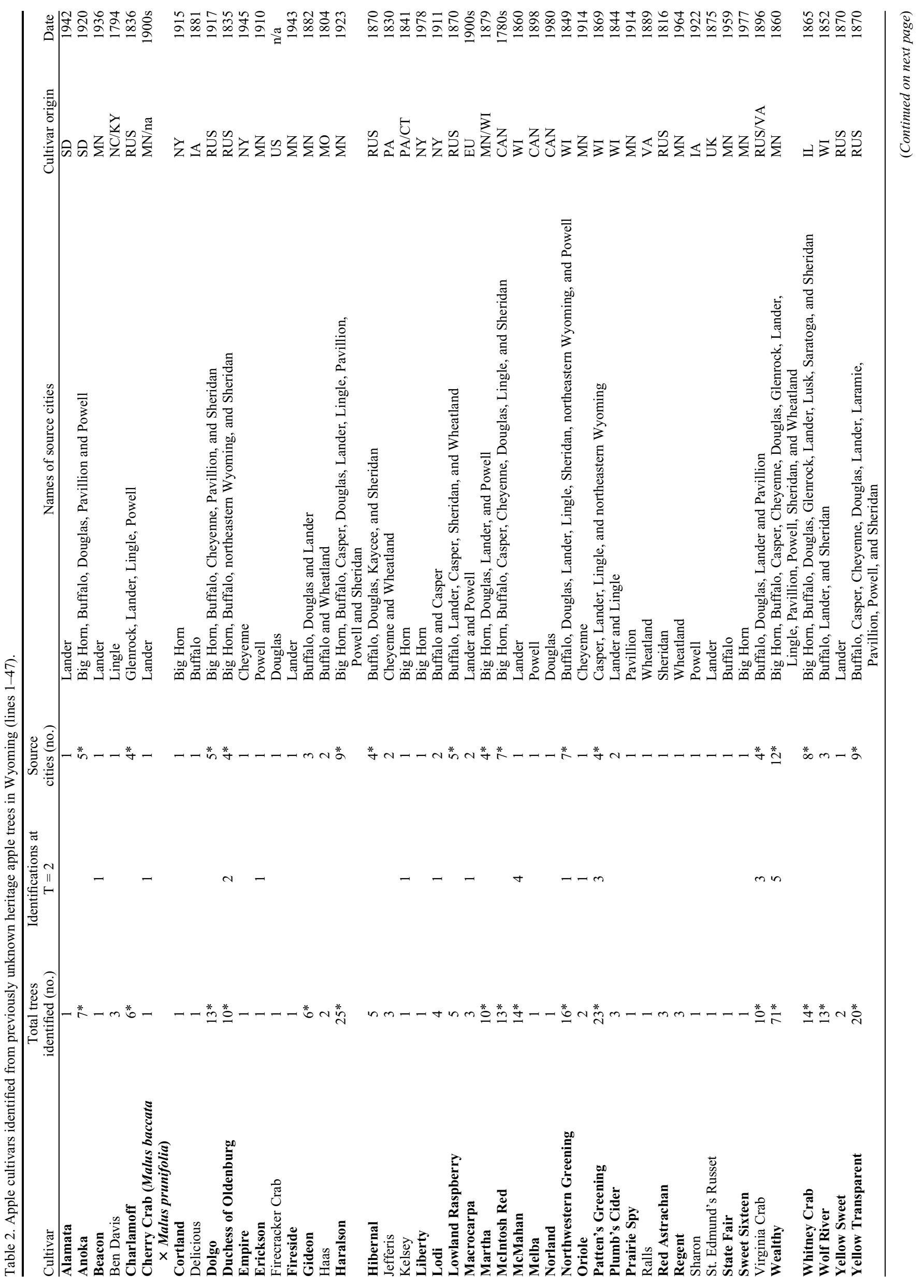




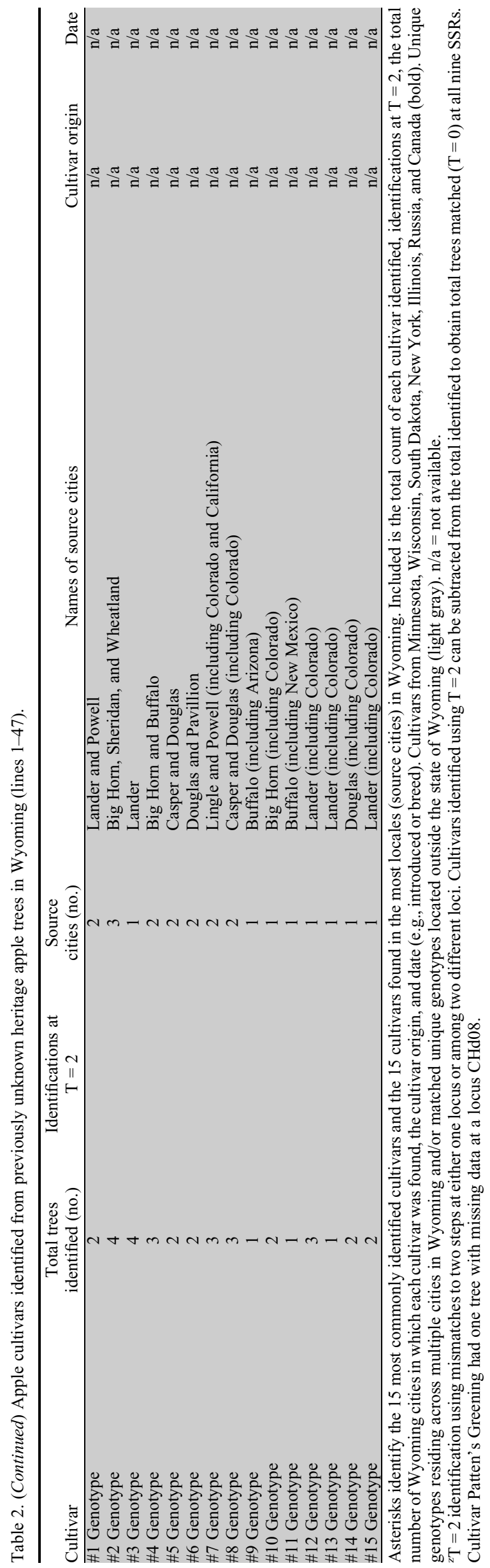

conditions by the University of Wyoming Lander Experimental Fruit Farm and was mentioned 11 times in WGB and EFFB bulletins (Nelson, 1905, 1907, 1909, 1912, 1915, 1916, 1918a, 1918b, 1924-25; University of Wyoming Agricultural Experiment Station, 1897).

The 182 remaining unknown apple trees in our data set had 146 unique genotypes. Eight of those genotypes were found in two or more locales in Wyoming. Nine of the genotypes found in Wyoming matched unique genotypes from as yet unidentified trees located outside the state of Wyoming (e.g., Arizona, California, Colorado, and New Mexico; data not shown), with two of those genotypes found at multiple locales in Wyoming (Table 2).

Observed and expected heterozygosity were calculated using the 146 unique genotypes remaining in our data set and 47 known cultivars identified in our study. Two unique genotypes were missing data for either one or multiple microsatellites $(\mathrm{N}=191)$. Average observed heterozygosity $\left(H_{0}=0.782\right)$ was calculated and found to be $0.019>H_{e}$ (Table 4). $H_{o}$ was found to be lower than $H_{\mathrm{e}}$ at microsatellites Ch01h01, GD15, GD142, and GD162 and higher than expected at all other microsatellites.

To provide evidence that the combined data sets were sufficient to determine clonal duplicates, multilocus probability of identity (ProbI) was calculated in GenAlEx 6.5 (Peakall and Smouse, 2006). Both the standard ProbI $\left(2.1 \times 10^{-12}\right)$ and conservative $\operatorname{Prob}_{\text {sibs }}\left(1.4 \times 10^{-4}\right)$ were calculated for the 1721 samples (510 unknowns and 1211 references). The probability that the matches are due to chance can be translated as 1 in 7100 if siblings are considered and a 1 in 476 billion when siblings are not considered. Individuals in our data set maybe related, so the real value likely falls somewhere between these two extremes (Gross et al., 2012, 2018).

\section{Discussion}

Sampling. The historic apple trees sampled in this work were found in old orchards and homesteads and represent trees from the start (1870) to the decline (1940) of apple production in Wyoming. The apple decline in Wyoming began with the rise in popular agricultural crops (i.e., wheat, alfalfa, and corn) and livestock (i.e., cattle) around 1920-30 (Nelson, 1905, 1907, 1909, 1912, 1915, 1916, 1918a, 1918b, 1924-25). Additionally, the introduction of supermarkets likely decreased the dependency on local fruit crop production. Sampling preference in the present study was given to cities and other locales with a high level of documentation of heritage apple production; therefore, no sampling was conducted in the southwestern portion (west of Saratoga and south of Riverton) of Wyoming because there was only a single documented site (e.g., Afton, WY) of apple production listed in available Wyoming extension bulletins (Magby and Miller, 2018).

Previous studies. Our research complements previous studies performed in the 
Table 3. Mean annual temperature (MAT), minimum temperature, maximum temperature, and mean annual precipitation (MAP) for Wyoming cities where trees were sampled and states and/or countries from which cultivars originated (Clima Temps, 2017a, 2017b; National Oceanic and Atmospheric Administration, 2018; US Climate Data, 2018).

\begin{tabular}{llcccc}
\hline Country/state & \multicolumn{1}{c}{ City } & MAT $\left({ }^{\circ} \mathrm{C}\right)$ & MAT-min $\left({ }^{\circ} \mathrm{C}\right)$ & MAT-max $\left({ }^{\circ} \mathrm{C}\right)$ & MAP $(\mathrm{cm})$ \\
\hline Canada & Ottawa & 6 & 1.2 & 10.7 & 86.9 \\
Minnesota & St. Paul & 7.2 & 2 & 12.4 & 70.6 \\
New York & Syracuse & 8.8 & 3.6 & 14 & 97 \\
Russia & Moscow & 5 & -0.4 & 8.3 & 68.8 \\
South Dakota & Sioux Falls & 7.5 & 1.3 & 13.7 & 62.5 \\
Wisconsin & Madison & 7.7 & 1.8 & 13.6 & 80.8 \\
Wyoming & Big Horn & $\mathrm{n} / \mathrm{a}$ & $\mathrm{n} / \mathrm{a}$ & $\mathrm{n} / \mathrm{a}$ & $\mathrm{n} / \mathrm{a}$ \\
Wyoming & Buffalo & 7.3 & 0.5 & 14.1 & 33.8 \\
Wyoming & Burns & $\mathrm{n} / \mathrm{a}$ & $\mathrm{n} / \mathrm{a}$ & $\mathrm{n} / \mathrm{a}$ & $\mathrm{n} / \mathrm{a}$ \\
Wyoming & Casper & 7.4 & 0.1 & 14.8 & 31 \\
Wyoming & Cheyenne & 7.1 & 0.6 & 13.7 & 37.3 \\
Wyoming & Douglas & 7.6 & -0.6 & 15.8 & 32 \\
Wyoming & Glenrock & 8.8 & 1.4 & 16.3 & 31 \\
Wyoming & Kaycee & 7.5 & -0.8 & 14.3 & 31.5 \\
Wyoming & Keeline/Lusk & 6.7 & -0.9 & 14.3 & 42.2 \\
Wyoming & Lander & 6.7 & -0.2 & 13.2 & 33.8 \\
Wyoming & Laramie & 5.1 & -3.1 & 17.1 & 29.21 \\
Wyoming & Lingle & 8.5 & -0.1 & 15.2 & $\mathrm{n} / \mathrm{a}$ \\
Wyoming & Northeastern corner & 7.9 & 0.6 & $\mathrm{n} / \mathrm{a}$ & 43 \\
Wyoming & Pavillion & $\mathrm{n} / \mathrm{a}$ & $\mathrm{n} / \mathrm{a}$ & 14.7 & $\mathrm{n} / \mathrm{a}$ \\
Wyoming & Powell & 6.9 & -0.9 & 15 & 17.3 \\
Wyoming & Riverton & 6.9 & -1.2 & 13.9 & 21.4 \\
Wyoming & Saratoga & 6.2 & -1.5 & 17.8 & 26.2 \\
Wyoming & Sheridan & 7.2 & -0.4 & 38.1 \\
Wyoming & Wheatland & 9.8 & 1.7 & & 34.8 \\
\hline
\end{tabular}

$\mathrm{n} / \mathrm{a}=$ not available.

Table 4. Observed heterozygosity $\left(H_{\mathrm{o}}\right)$, expected heterozygosity $\left(H_{\mathrm{e}}\right)$, observed number of alleles, and probability of identify for unknown samples.

\begin{tabular}{llccc}
\hline Microsatellite marker & $H_{\mathrm{o}}$ & $H_{\mathrm{e}}$ & Observed no. of alleles & ProbI \\
\hline CH01f02 & 0.937 & 0.913 & 20 & 0.016 \\
CH01h01 & 0.78 & 0.804 & 17 & 0.036 \\
CH02d08 & 0.817 & 0.803 & 17 & 0.049 \\
GD12 & 0.812 & 0.798 & 17 & 0.076 \\
GD15 & 0.126 & 0.133 & 3 & 0.86 \\
GD96 & 0.916 & 0.88 & 16 & 0.024 \\
GD142 & 0.885 & 0.878 & 16 & 0.024 \\
GD147 & 0.895 & 0.815 & 15 & 0.045 \\
GD162 & 0.846 & 0.848 & 16 & 0.034 \\
& Mean $=0.782$ & Mean $=0.763$ & Mean $=15.222$ & Cumulative probability \\
& & & & $=2.1 \times 10^{-12}$ \\
\hline
\end{tabular}

Means for each diversity statistic are provided.

${ }^{\mathrm{z}} H_{\mathrm{o}}, H_{\mathrm{e}}$, and number of alleles were calculated using the 146 unique genotypes and 47 identified cultivars across all nine microsatellites. ProbI for individual markers was calculated using the entire data set (510 previous unknowns +1211 known cultivars), including a cumulative probability using all nine microsatellites.

southwestern United States and in Minnesota. Routson et al. (2009) sampled 280 apple trees from abandoned homesteads and orchards across four southwestern states (e.g., Colorado, Utah, Arizona, and New Mexico). Genetic analyses showed 34 cultivars (120 samples) across 43 historical sites and 110 unique fingerprints in the remaining unidentified 160 samples. The top five cultivars found by Routson et al. (2009) were Jonathan (17), Ben Davis (16), Winesap (13), Delicious (12), and Grimes Golden (7). There were 11 cultivars that overlapped between our data set and those that were published by Routson et al. (2009): Ben Davis, Delicious, Wolf River, Red Astrachan, Duchess, Lowland Raspberry, McIntosh, Northwestern Greening, Ralls, Wealthy, and Yellow Transparent (Routson et al., 2009) (Table 2).

Gross et al. (2018) assessed the impact of local breeding programs through the identi-
Wyoming. It is likely that cold hardy cultivars found in both Wyoming and Minnesota are well adapted to the cooler and/or harsher winters compared with warmer climates found in southwestern states (Table 2).

Routson et al. (2009) used 144 unique genotypes (i.e., compared with our 191) to calculate $H_{o}, H_{e}$ and total alleles. Six of the seven microsatellites are shared with the present study and reported on average observed heterozygosity higher than expected by 0.047 . Of the six microsatellites used in the current work and by Routson et al. (2009), GD12 had six more alleles, GD15 (1), GD96 (2), GD142 (3), GD147 (3), and GD162 (3) respectively, than identified in the southwest cultivars. Similar to our study, Routson et al. (2009) had no higher than expected observed alleles for microsatellites. Gross et al. (2018) observed higher than expected allele counts at $\mathrm{Ch} 010 \mathrm{f0} 2$ and $\mathrm{Ch} 02 \mathrm{~d} 08$. Gross et al. (2018) reported levels of diversity $\left(H_{e}=\right.$ $0.755)$ similar to our study $\left(H_{e}=0.782\right)$ using all nine microsatellites, with a total difference of $H_{e}=0.027$ (Table 4). The diversity of Wyoming cultivars, as measured using $H_{e}, H_{o}$, and total microsatellite alleles, is similar to that reported in other collections (Cornille et al., 2012; Gross et al., 2012, 2018; Routson et al., 2009). This suggests that regardless of the relatively limited geographic area studied (Wyoming), the genetic variability of Wyoming's apples was as high as sampling performed over greater geographic distances.

Unknown genotypes. We had 146 unique genotypes among the remaining unknown apple trees $(\mathrm{N}=182)$. Eight of those genotypes (1-8) were found in more than two different locales in Wyoming (Table 2). Genotypes (1-6) could either be historical cultivars developed elsewhere and imported into Wyoming, or novel varieties developed and shared by local programs (Table 2). Finally, nine genotypes (7-15) found in Wyoming matched unique genotypes located outside the state (e.g., Arizona, California, Colorado, and New Mexico) (Table 2; data not shown). These genotypes are likely historical cultivars developed elsewhere and imported into Wyoming (i.e., missing in our standard cultivars) or are previously unidentified cultivars.

The samples that were represented by a single genotype that did not match the standard cultivars may be previously unidentified cultivars or novel varieties. Sites such as the University of Wyoming Lander Experimental Fruit Farm and Ed. Young Orchard (i.e., commercial orchards and/or stock sellers) have the highest likelihood of containing historic cultivars and could be 1) historical cultivars missing from our reference data set or 2) seedlings that are not identified cultivars.

Weather. Wyoming has some of the driest and coldest winters in the lower 48 states, with a ranking of fourth in average low temperature and fifth in average low precipitation (NOAA, 2018). Seventy-five percent of the apple cultivars that were identified 
in Wyoming originated from breeding programs located in other states (i.e., Minnesota, Wisconsin, South Dakota, New York, and Illinois) and countries (Canada and Russia) with similar average low winter temperatures (Table 3). Minnesota, Wisconsin, South Dakota, Russia, and Canada have mean average temperatures (MAT) that were most comparable to those of Wyoming (Table 3). The Wyoming towns of Laramie and Saratoga reported the lowest average and/or annual low temperatures, and Glenrock, Lingle, and Wheatland experienced the highest average and/or annual high temperatures (Table 3).

Moscow, Russia, and Ottawa, Canada, fall well above Wyoming mean average precipitation (MAP) with $68.8 \mathrm{~cm}$ and $86.9 \mathrm{~cm}$, along with Madison, WI $(80.8 \mathrm{~cm})$, Syracuse, NY $(97 \mathrm{~cm})$, and St. Paul, MN $(70.6 \mathrm{~cm})$ (Table 3). Powell $(17.3 \mathrm{~cm})$ and Riverton $(21.4 \mathrm{~cm})$ reported the lowest MAP, while northeast Wyoming $(43 \mathrm{~cm})$, Lusk $(42.2 \mathrm{~cm})$, and Sheridan $(38.1 \mathrm{~cm})$ experienced the highest MAP (Table 3) (Clima Temps, 2017a, 2017b; Climate Data, 2018).

The survival of many organisms is dependent on the seasonal range in temperature (i.e., minimum and maximum temperatures) rather than just MAT and MAP (Eberle and Greenwood, 2012). Among the 19 cities sampled, Lingle has the largest difference between maximum and minimum average temperatures $\left(17.2^{\circ} \mathrm{C}\right)$. It is 10 th in lowest minimum MAT $\left(-0.1{ }^{\circ} \mathrm{C}\right)$ but second highest in maximum MAT $\left(17.1^{\circ} \mathrm{C}\right)$. Cheyenne has the lowest fluctuation of MAT $\left(13.1{ }^{\circ} \mathrm{C}\right)$ in Wyoming. It is 13th in lowest minimum MAT $\left(0.6{ }^{\circ} \mathrm{C}\right)$ but second lowest maximum MAT $\left(13.7^{\circ} \mathrm{C}\right)$ (Table 3). South Dakota $\left(12.4^{\circ} \mathrm{C}\right)$ and Wyoming have comparable temperature fluctuations between minimum and maximum. Climatic data for Wyoming cities is provided to aid in the correlation between cultivar adaptation and climatic conditions to allow other states and regions of Wyoming to select cultivars based on their success under specific Wyoming conditions (NOAA, 2018; US Climate Data, 2018).

Breeding programs. Fifteen of the most commonly identified historic apple cultivars in Wyoming originated from breeding programs in Wisconsin, Russia, Minnesota, Canada, Illinois, and South Dakota (Tables 2 and 3). Sixty-two of 218 cultivars reported in WGB and EFFB bulletins during the 1870 s to 1940 s were from these locations (i.e., Russia, Wisconsin, and Minnesota). Additionally, 32 of the 47 cultivars identified in our study were bred or introduced around the time (1850-1950) apples were being produced in Wyoming. The popularity of 'Wealthy' may be the result of its promotion in Agricultural Extension Bulletins from 1870 through 1940. Although we observed that many heritage apple cultivars are reaching the end of their life span, trees identified to be Wealthy continue to produce fruit in locales throughout Wyoming (Fig. 1).

Conclusion. It is likely that a combination of popularity and cultivar origin affected the choice of cultivars that were grown in
Wyoming. Even though trees representing cultivars in our study are aging, often in an unmaintained state, many are still producing fruit. Our results provide insights for the first time for cultivars grown in Wyoming that could be grown across states with similar harsh winter conditions. Wealthy seedlings have already proven successful as a source of novel cultivars for Wyoming conditions. Hardy cultivars such as Wealthy could also be used in Wyoming breeding programs (Magby and Miller, 2018).

Specialty crop growers seeking cultivars that may succeed in Wyoming could extend their search to other cultivars bred in programs in New York, South Dakota, Wisconsin, Minnesota, Russia, and Canada. This would help increase the diversity of cultivars grown in Wyoming. Cultivars previously tested at the University of Wyoming Lander Experimental Fruit Farm from states with similar winter conditions and recommended (i.e., Excellent and/or Fair) for Wyoming growing conditions are as follows: Minnesota (August, Estaline, Hutchins, Jewell Sweet, Jewell's Winter, Judson, Lou, Malinda, Minnehaha, Minnetonka, October, Okabena, Peerless and Peter), Wisconsin (Berlin, Harry Kaump, Pewaukee, Snyder, Walbridge, and Windsor), New York (Early Harvest, Jonathan, and Wagner), Russia (Alexander, Antonovka, Boronvinka, Christmas, Enormous, Longfield, Repka Malenka, Summer Pear, Tetofsky and Zuzoff's Winter) and Canada (Ball Pacific and Fameuse) (Bussey and Whealy, 2016; Magby and Miller, 2018; Nelson, 1905, 1907, 1909, 1912, 1915, 1916, 1918a, 1918b, 1924-25; and University of Wyoming Agricultural Experiment Station, 1897).

\section{Literature Cited}

Burford, T. 2013. Apples of North America: 192 Exceptional Varieties for Gardeners, Growers and Cooks. Timber Press, Portland, OR.

Bussey, D.J. and K. Whealy. 2016. The Illustrated History of Apples in the United States and Canada. Vols. 1-7, ser. 1. JAK KAW Press, Mount Horeb, WI.

Calhoun, C.L. 2010. Old Southern Apples: A Comprehensive History and Description of Varieties for Collectors, Growers and Fruit Enthusiasts. Chelsea Green Publishing, White River Junction, VT.

Clima Temps. 2017a. Average Temperatures in Moscow, Russia: Map. 1 Apr. 2018. <http:// www.Moscow/climatemps.comtemperatures. php>.

Clima Temps. 2017b. Average Temperatures in Ottawa, Canada: Map. 1 Apr. 2018. <http:// www.Moscow/climatemps.comtemperatures. php>.

Cornille, A., P. Gladieux, M.J.M. Smulders, I Roldan-Ruiz, F. Laurens, B. Le Cam, A. Neresyan, J. Clavel, M. Olonova, L. Feugey, I. Gabreilyan, X.-G. Zhang, M.I. Tenaillon, and T. Giraud. 2012. New insight into the history of domesticated apple: Secondary contribution of the European wild apple to the genome of cultivated varieties. PLoS Genet. 8:e1002703.

Eberle, J.J. and D.R. Greenwood. 2012. Life at the top of the greenhouse eocene world-a review of the eocene flora and vertebrate fauna from
Canada's high Arctic. Geol. Soc. Amer. Bull. 124:3-23, doi: 10.1130/b30571.1.

Gross, B.L., G.M. Volk, C.M. Richards, P.L. Forsline, G. Fazio, and C.T. Chao. 2012. Identification of "duplicate" accessions within the USDA-ARS National Plant Germplasm system Malus collection. J. Amer. Soc. Hort. Sci. 137:333-342.

Gross, B.L., M.J. Wedger, M. Martinez, G.M. Volk, and C. Hale. 2018. Identification of unknown apple cultivars demonstrates the impact of local breeding program on cultivar diversity. Genet. Resources Crop Evol. 65:1317-1327, doi: 10.1007/s10722-018-0625-6.

Hokanson, S.C., A.K. Szewc-McFadden, W.F. Lamboy, and J.R. McFerson. 1998. Microsatellite (SSR) markers reveal genetic identities, genetic diversity and relationships in a Malus $x$ Domestica Borkh. Core subset collection. Theor. Appl. Genet. 97:671-683, doi: 10.1007/ s001220050943.

Magby, J.T. and S.L. Miller. 2018. Wyoming Apple Project: Steve Miller Lab. Univ. of Wyoming, Laramie. 1 Mar. 2018. <http://www. wyomingappleproject.com/>.

Miller, S.L. 2014. Wyoming Apple Project: Attempts to save Wyoming's diverse apple cultivars. Barnyards and Backyards. Univ. of Wyoming. 1 Mar. 2018. <www.uwyo.edu/ barnbackyard/_files/documents/magazine/ 2014/winter/010114bbwyappleproject.pdf>.

Morneau, D., S. Miller, T. Craig, J. States, V. Layton, B. Foss, and A. Eckart. 2016. Orchard Restoration Project: Historic orchard restoration project. Central Wyoming College. 1 Mar. 2018. <https://www.cwc.edu/orchard/>.

National Geographic Society. 2014. Wyoming Tabletop Map. Edited by National Geographic Society. 1 Apr. 2018. <http://www.nationalgeographic.org/maps/wyoming-tabletop-map/>.

Nelson, A. 1905. First Biennial Report. Vol. 2. Wyoming State Board of Horticulture, Univ. of Wyoming.

Nelson, A. 1907. Second Biennial Report. Vol. 2. The Wyoming State Board of Horticulture, Univ. of Wyoming.

Nelson, A. 1909. Third Biennial Report. Vol. 3. Wyoming State Board of Horticulture, Univ. of Wyoming.

Nelson, A. 1912. General Notes: The State Experimental Fruit-Farm-The Horticultural Society. Vol. 1, No. 3. Publications of the Wyoming State Board of Horticulture. Univ. of Wyoming.

Nelson, A. 1915. Sixth Biennial Report. Vol. 6, No. 104. Wyoming State Board of Horticulture, Univ. of Wyoming.

Nelson, A. 1916. Horticulture and the Home. Vol. 1, No. 5. Publications of the Wyoming State Board of Horticulture, Univ. of Wyoming.

Nelson, A. 1918a. War-Time Horticulture Index. Vol. 1, No. 6. Publications of the Wyoming State Board of Horticulture. Univ. of Wyoming.

Nelson, A. 1918b. Seventh Biennial Report. Vol. 7 , Publications of the Wyoming State Board of Horticulture, Univ. of Wyoming.

Nelson, A. 1924-25. Wyoming Experimental Station: The State Experimental Fruit Farm. 2nd ed., Vol. 3. Wyoming State Board of Horticulture. $<$ repository.uwyo.edu/ag_exp_sta_bulletins/.

National Oceanic and Atmospheric Administration. 2018. National Centers for Environmental information: Climate at a Glance (1901-2000). Statewide Mapping. Minimum Temperature. 1 Apr. 2018. <http://www.ncdc.noaa.gov/cag/>.

Peakall, R. and P.E. Smouse. 2006. GENALEX 6: Genetic analysis in Excel. Population genetic software for teaching and research. 
Mol. Ecol. Notes 6:288-295, doi: 10.1111/ j.1471-8286.2005.01155x.

Routson, K.J., A.A. Reilley, A.D. Henk, and G.M. Volk. 2009. Identification of historic apple trees in the Southwestern United States and implications for conservation. HortScience 44:589-594.

Smith, M.W.G. 2002. National Apple Register of the United Kingdom. Langford Press Wingtown, Scotland. (Reprinted by Castlepoint Press).
University of Wyoming Agricultural Experiment Station. 1897. Fruit Growing in Wyoming. Univ. of Wyoming, Bul. 34:86157. 1 May 2016. <http://repository.uwyo. edu/ag_exp_sta_bulletins/35/>.

U.S. Climate Data. 2018. Climate Cities: Wyoming and Weather Averages. Temperature. Rainfall and Snowfall. 1 Apr. 2018. <www. usclimatedata.com/climate/climate/cheyenne/ wyoming/united-states/uswy0032>.
Volk, G.M., C.M. Richards, A.A. Reilley, A.D. Henk, P.L. Forsline, and H.S. Aldwinckle. 2005. Ex situ conservation of vegetatively propagated species: Development of a seedbased core collection for Malus sieversii. J. Amer. Hort. Sci. 130:203-210.

Wünsch, A. and J.I. Hormaza. 2001. Cultivar identification and genetic fingerprinting of temperate fruit tree species using DNA markers. Euphytica 125:59-67. 